\title{
Study on the Mechanical Properties of Clay- Fly Ash Mixture
}

\author{
Muhammad Babur Nazaroghlu \\ Civil Engineering Department, Faculty of Engineering, \\ Istanbul Aydin University, \\ Istanbul, Turkey
}

\author{
Kaveh Dehghanian \\ Civil Engineering Department, Faculty of Engineering, \\ Istanbul Aydin University, \\ Istanbul, Turkey
}

\begin{abstract}
In this research, one of the most effective soil remediation methods in clay soils is investigated using fly ash. Consolidation settlement of clayey soils is one of the major parameters which are essential to be controlled before any construction. In order to control this parameter, consolidation test is used to determine the rate and magnitude of soil consolidation when the soil is restrained laterally and loaded axially. In this study, to study the effect of fly ash in improving the physical properties of clay, fly ash content was increased as $(0 \%, 5 \%, 10 \%, 15 \%$, and $20 \%)$. Moreover Sieve analysis, water content test, Atterberg limits, and Standard Proctor tests were performed for the same percentage. It was observed that by adding fly ash, plasticity of sample decreases. Furthermore, $15 \%$ mixture gives the lowest consolidation coefficient result; therefore it is advised to implement this percentage in fields.
\end{abstract}

Keywords: Fly Ash, Ground improvement, Consolidation test

\section{INTRODUCTION}

Fly ash which is obtained from coal burning in thermal power plants is produced in large quantities around the world. Low-volume weight, high-shear strength, low compressibility, insensitivity to moisture are some of the positive characteristics of fly ash and play an important role in the development of the engineering properties of soils $[1,2]$. Soil stabilization is a method of improving soil properties by mixing and mixing other materials.

There are various methods of soil clearing and there are various materials for use. One of them is the addition of fly ash [3]. In addition, it is possible to use a large amount of fly ashes in geotechnical engineering works, such as filling the dam and on the road. There are different and even controversial results in the literature. For instance, the effect of the increase of fly ash over the free shear strength is low [4]. In other studies, the free ash strength increase was reported when the ash ratio increased [5]. In this study, the effect of ash was investigated on the physical and mechanical behavior of clay using different ash percentage.

\section{MATERIALS AND METHODS}

In this study, the effect of fly ash was investigated on Illite clay. This type of clay has been chosen due to its plasticity and swelling characteristics. The $(0 \%, 5 \%, 10 \%$, $15 \%, 20 \%$ and $25 \%$ ) fly ash percentage was used in all experiments. Sieve analysis, determination of water content, Atterberg Limit, specific gravity, Standard Proctor and consolidation tests are performed in this study. The fly ash value has been increased as $20 \%$ in consolidation test. In all experiments, type $\mathrm{C}$ fly ash was used. Type $\mathrm{C}$ fly ash contains from $15 \%$ to $35 \% \mathrm{CaO}$ and is obtained by combustion of non-coal and other lignite. This type of fly ash has a high calcium content as well as pozzolanic properties and binding feature [6]. Fly ash type is usually determined according to ASTM C618 [7]. All experiments were performed in accordance with TS 1500, TS1900-1 and TS1900-2 standards $[8,9,10]$. The notations related to the test samples are given in Table 1.

\section{TABLE 1. INDICATIONS ABOUT TEST SAMPLES}

\begin{tabular}{ll}
\hline Mixing ratios of test samples & \multicolumn{1}{c}{ Title 2 } \\
\hline Clay & $\mathrm{k}$ \\
Clay and $5 \%$ fly ash & $\mathrm{KFA} / 5$ \\
Clay and $10 \%$ fly ash & $\mathrm{KFA} / 10$ \\
Clay and $15 \%$ fly ash & $\mathrm{KFA} / 15$ \\
Clay and 20\% fly ash & $\mathrm{KFA} / 20$ \\
Clay and 25\% essential & $\mathrm{KFA} / 25$ \\
\hline
\end{tabular}

\section{A. Determination of Specific Gravity:}

The specific gravity $\left(\mathrm{G}_{\mathrm{s}}\right)$ of the soils is necessary to determine the volume and weight relationship. TS 1900-1 standard was applied in the experiment. Each experiment was repeated 3 sets and the mean value was recorded. The figure below is clearly shown.

TABLE 2. SPECIFIC GRAVITY OF SAMPLES

\begin{tabular}{clc}
\hline Fly ash(\%) & Material & Average $\mathbf{G}_{\mathbf{s}}$ \\
\hline 0 & Fly ash & 2.02 \\
0 & illit clay & 2.83 \\
$\% 5$ & Fly ash + Clay & 2.91 \\
$\% 10$ & Fly ash + Clay & 2.44 \\
$\% 15$ & Fly ash + Clay & 2.39 \\
$\% 20$ & Fly ash + Clay & 2.40 \\
$\% 25$ & Fly ash + Clay & 2.42 \\
\hline
\end{tabular}

\section{B. Sieve Analysis:}

The particle size distribution of the soil materials is defined as well graded or poorly graded [9]. All experiments were performed according to TS 1900-2. For sieve analysis, the sample is heated for 24 hours in the oven at an average of $105^{\circ \mathrm{C}}$. The sample was washed on the sieve no.200 (0.075 $\mathrm{mm}$ ) to eliminate the dust from the sample. The remaining sample on the screen was allowed to get dried for 24 hours. Then the remaining sample was weighed and the amount of loss during washing was determined. Afterward, the sample was sieved from large to small sieves ( 3 ", $1 \frac{1}{2} 2$, 3/4 ", 3/8", 4 \#, 10 \#, 16 \#, 40 \#, 100 \# and 200 \#). The 
results of the granulometry curve is presented in table 3 and figure 1.

TABLE 3. RESULT OF SIEVE ANALYSIS

\begin{tabular}{|c|c|c|c|c|c|}
\hline \multicolumn{2}{|c|}{ weight of wit soil } & 463.97 & & & \\
\hline \multicolumn{2}{|c|}{ Dry Sample Weight } & 455.32 & & & \\
\hline \multicolumn{2}{|c|}{ Dry Sample Weight } & 455.32 & \multicolumn{3}{|c|}{ Gravel + Sand + Silt + Clay } \\
\hline \multicolumn{2}{|c|}{$\begin{array}{c}\text { Dry Sample Weight After } \\
\text { Washing }\end{array}$} & 23.14 & \multicolumn{3}{|c|}{ Gravel + Sand } \\
\hline $\begin{array}{l}\text { SIEVE } \\
\text { NO }\end{array}$ & $\begin{array}{l}\text { SIEVE Left } \\
\quad(\mathrm{gr})\end{array}$ & $\begin{array}{l}\text { Total } \\
\text { Left } \\
(\mathrm{gr})\end{array}$ & $\begin{array}{c}\text { Total } \\
\text { Pass(gr) }\end{array}$ & $\begin{array}{l}\text { Total } \\
\text { Pass } \\
(\%)\end{array}$ & $\begin{array}{l}\text { Weight of } \\
\text { Sieve(mm) }\end{array}$ \\
\hline \multirow[t]{2}{*}{ 3" } & 0.00 & 0.00 & 455.3 & 100 & 75 \\
\hline & 0.00 & 0.00 & 455.3 & 100 & 63 \\
\hline \multirow[t]{3}{*}{$1,5^{\prime \prime}$} & 0.00 & 0.00 & 455.3 & 100 & 40 \\
\hline & 0.00 & 0.00 & 455.3 & 100 & 20 \\
\hline & 0.00 & 0.00 & 455.3 & 100 & 9.5 \\
\hline 4 & 0.00 & 0.00 & 455.32 & 100.00 & 4.75 \\
\hline \multirow[t]{5}{*}{10} & 0.18 & 0.18 & 455.14 & 99.96 & 2 \\
\hline & 0.00 & 0.18 & 22.96 & 99.22 & 1.4 \\
\hline & 0.19 & 0.37 & 454.95 & 99.92 & 1.19 \\
\hline & 0.55 & 0.92 & 454.40 & 99.80 & 0.600 \\
\hline & 0.00 & 0.92 & 22.22 & 96.02 & 0.500 \\
\hline \multirow[t]{5}{*}{40} & 0.64 & 1.56 & 453.76 & 99.66 & 0.425 \\
\hline & 0.78 & 2.34 & 452.98 & 99.49 & 0.300 \\
\hline & 0.00 & 2.34 & 20.80 & 89.89 & 0.250 \\
\hline & 9.45 & 11.79 & 443.53 & 97.41 & 0.150 \\
\hline & 10.85 & 22.64 & 0.50 & 2.16 & 0.125 \\
\hline$\# 200$ & 0.50 & 23.14 & 432.18 & 94.92 & 0.063 \\
\hline PAN & 0.50 & & & & \\
\hline
\end{tabular}

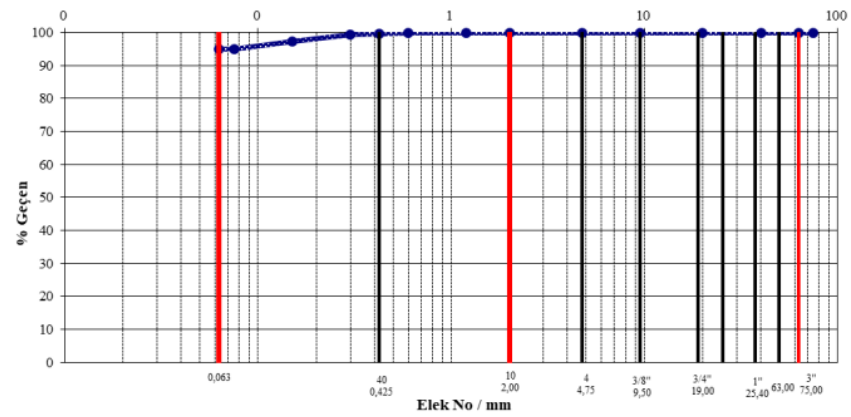

Fig 1. Grain size distribution curve of clay material

\section{Standard proctor test and determination of optimum water content:}

The purpose of this experiment is to determine the optimum water content of the sample. The test was prepared according to TS 1900-1 standard. The results obtained from the experiment are given in figure 2 .

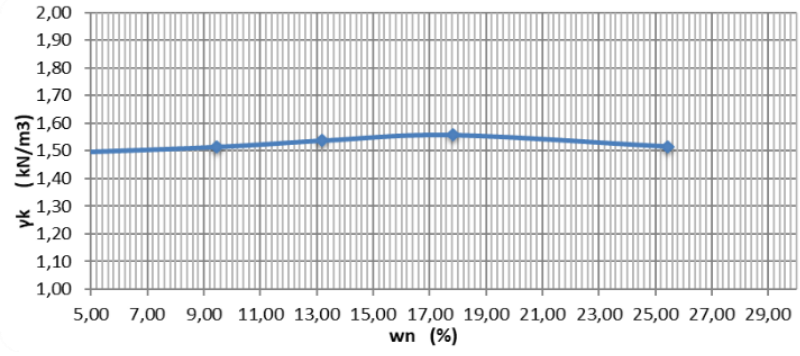

Fig 2. Grain size distribution curve of clay material

As a result of the experiment, the maximum dry unit volume weight was found to be $1.56 \mathrm{gr} / \mathrm{cm}^{3}$ and the water content was determined as $17.87 \%$.

D. Atterberg limits:

The Atterberg limits are a basic measure of the critical water contents of a fine-grained soil: its shrinkage limit, plastic limit, and liquid limit. Depending on its water content, a soil may appear in one of four states: solid, semisolid, plastic and liquid [11]. At the liquid limit, the ground can flow slowly under its own weight. In plastic case, the desired shape can be easily supplied to the floor. In the semi-solid state, the desired shape is hardly given to the soil, cracking occurs on the soil. The soil cannot be formed in solid condition [12]. The results used to determine the engineering properties of primary clay material are presented in Table 4. In this table, the classification of the soil is made according to the Unified Soil Classification (USCS) ASTM D2487 - 17 [13]. According to the USCS classification, the sample was identified as low-plastic clay (CL).

TABLE 4. CHARACTERISTICS OF SOIL SAMPLE

\begin{tabular}{|l|c|}
\hline USCS classification & CL \\
Liquid limit, LL $(\%)$ & 38,22 \\
Plastic limit, PL $(\%)$ & 20,04 \\
Plasticity index, PI $(\%)$ & 18,18 \\
Specific Gravity, $\mathrm{G}_{\mathrm{s}}$ & 2,02 \\
Optimum water content, $\mathrm{w}_{\mathrm{opt}}(\%)$ & 17,87 \\
Maximum dry density, $\left(\gamma_{\max }\left(\mathrm{Mg} / \mathrm{m}^{3}\right)\right.$ & 1,56 \\
\hline
\end{tabular}

In this study, the liquid limit and plastic limit test results on the sample mixtures are given in the table 5 . It can be concluded that the increase in fly ash ratio results in decrease in the Plasticity Index (PI).

TABLE 5. ATTERBERG LIMITS OF SAMPLES

\begin{tabular}{|lclc|}
\hline $\begin{array}{l}\text { Test Samples } \\
(\%)\end{array}$ & Likit Limit (\%) & Plastik Limit (\%) & Plasticity Index \\
K & 38.22 & 20.04 & 18.18 \\
KFA/5 & 45,0 & 34,0 & 11,0 \\
KFA/10 & 44,5 & 33,7 & 10,8 \\
KFA/15 & 44,5 & 33,7 & 10,8 \\
KFA/20 & 43,4 & 33,2 & 10,2 \\
KFA25 & 40.62 & 31,09 & 9,53 \\
\hline
\end{tabular}

E. Consolidation test:

Consolidation test is used to determine the rate and magnitude of soil consolidation when the soil is restrained laterally and loaded axially. The Consolidation test is also referred to as Standard Odometer test or One-dimensional 
compression test. This test is carried out on saturated soil specimens, especially in cohesive soils. The consolidation parameters obtained by this test are used to determine the consolidation settlement and time of consolidation for a given loading state (i.e. given height of embankment). These parameters are also used in design of "Ground Improvement measures", provided for construction of embankment on soft soils [14]. Under the stresses of the clay under constant stress depending on the time of the water jams in the event of consolidation is called consolidation in a period of time in the clay layer will be caused by an effective stress increase in the layer will be sitting [15]. This process is caused by an increase in the total stress, while the excess pore water pressure continues until it is completely dispersed; the simplest consolidation state is the only one-way consignment swelling cycle that takes place in the case of zero lateral deformation is the slow increase in the volume of a floor under the negative pore water pressure. The consolidation experiment was made with different additive clay and fly ash. Ash ratios vary from $0 \%, 5 \%, 10 \%, 15 \%, 20 \%$ After consolidation test sample preparation and test of the mixtures prepared with fly ash, the sample is shown in figure 3 .
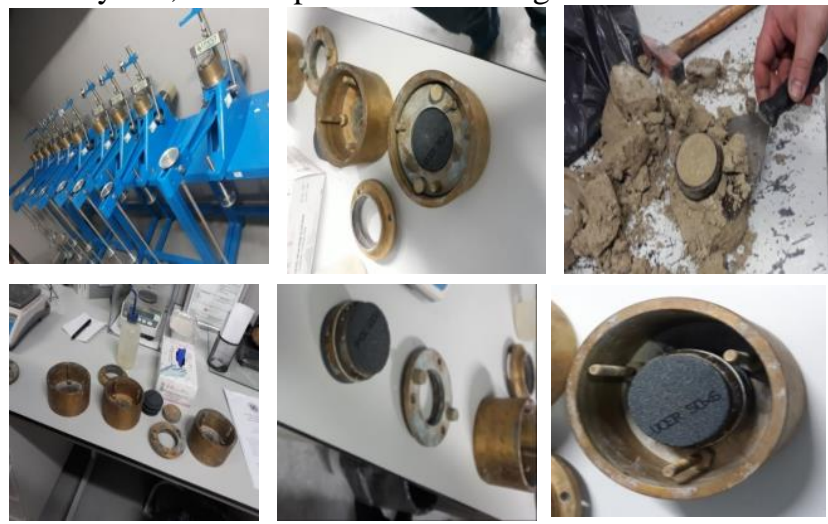

Figure 3. Consolidation test Steps pictures

Generally, the consolidation test is performed in figure 2. In the laboratory environment, this is the experiment that represents the best consolidation experiment. The result calculated at the end of the test is shown in table 6 .

TABLE 6. DIFFERENT BLENDS RESULTS OF CONSOLIDATION

\begin{tabular}{|l|c|c|c|c|c|c|}
\hline \multirow{2}{*}{$\%$} & \multicolumn{2}{|c|}{$\mathrm{e} 0$} & $\mathrm{Cv}$ & $\begin{array}{c}\text { Ortalama } \\
\text { Numune }\end{array}$ & \multirow{2}{*}{$\begin{array}{c}\mathrm{mv} \\
\mathrm{m}^{2} / \mathrm{kN}\end{array}$} & $\mathrm{K}$ \\
\cline { 2 - 5 } & $\begin{array}{c}\text { Start } \\
\text { of the } \\
\text { test }\end{array}$ & $\begin{array}{c}\text { End of } \\
\text { the test }\end{array}$ & $\begin{array}{c}\mathbf{m m}^{2} / \mathbf{m i} \\
\mathbf{n}\end{array}$ & Height(mm) & & \\
\hline $0 \%$ & 0.92 & 0.8033 & 0.0539 & 19.773 & 0.05411 & 0.02681 \\
\hline $5 \%$ & 0.92 & 0.77 & 0.05436 & 19.6 & 0.05453 & 0.02907 \\
\hline $10 \%$ & 0.92 & 0.73 & 0.05217 & 19.4 & 0.05203 & 0.02686 \\
\hline $15 \%$ & 0.92 & 0.8733 & 0.05202 & 19.46 & 0.0525 & 0.02680 \\
& & & & & & 7 \\
\hline $20 \%$ & 0.92 & 0.866 & 0.0532 & 19.6 & 0.05311 & 0.02771 \\
\hline
\end{tabular}

\section{RESULTS}

In this study,several analysis and tests such as Sieve Analysis, Water content, Atterberg limits, Proctor test, and consolidation test were performed to study the mechanical behavior of clay- fly ash mixture.

In addition, the plasticity index, and consequently the potential for swelling potential were studied. It was observed that addition of fly ash decreases the swelling of clayey soils. It was also concluded that by addition of $15 \%$ of the additive, the consolidation rate and the permeability (k) reduces significantly. It can be concluded that the best and optimum percentage of additive is $15 \%$ and higher amounts does not affect the behavior of mixture.

\section{REFERENCES}

[1] Sivapullaiah P. V., Prashanth J.P., Sridharan Asuri, Optimization of lime content for flyash, ASTM Journal of testing and evaluation 1995, 23: 3, 222-227.

[2] Ghosh A., Subbarao C., Tensile strength, bearing ratio and slake durability class F flyash stabilized with lime and gypsum, Journal of Materials in Civil Engineering (ASCE) 2006, 18:18-27.

[3] Olugbenga O. Amu1, Akinwole A. Adetuberu" Characteristics of Bamboo Leaf Ash Stabilization on Lateritic Soil in Highway Construction"

[4] Gaciarz, R. Stabilization of Silty Soil using Fly Ash, M.Sc. Thesis, Department of Engineering, Central Connecticut State University, New Britain, CT, 2012

[5] Ansary, M.A., Noor, M.A., Islam, M.Effectof flyash stabilization on geotechnical properties of chittagong coastal soil. In: Proceedings of the Geotechnical Symposium on Soil StressStrain Behavior, Rome, Italy, March 16-17 2006, p. 443-454.

[6] Bulut Ü, Tanaçan L. Perlitin puzolanik aktivitesi. İtü Dergisi A 2009; 8(1): 81-89.

[7] ASTM C618-19. Standard Specification for Coal Fly Ash and Rawor Calcined Natural Pozzolan for Use in Concrete, ASTM International, West Conshohocken, PA, 2019.

[8] TS 1900-1. İnşaat Mühendisliğinde Zemin Lâboratuvar Deneyleri - Bölüm 1: Fiziksel Özelliklerin Tayini. Türk Standardları Enstitüsü, Ankara, 2006.

[9] TS 1900-2. İnşaat Mühendisliğinde Zemin Lâboratuvar Deneyleri - Bölüm 2: Mekanik Özelliklerin Tayini. Türk Standardlar Enstitüsü, Ankara, 2006.

[10] Amer, A.M., and Awad, A.A. (1974) "Permeability of Cohesionless soil", Journal of the Geotechnical Engieeing Division, ASCE, 100: GT12, 1309-1316.

[11] https://en.wikipedia.org/wiki/Atterberg_limits.

[12] Amer, A.M., and Awad, A.A. (1974) "Permeability of Cohesionless soil", Journal of the Geotechnical Engieeing Division, ASCE, 100: GT12, 1309-1316.

[13] ASTM D2487-17, Standard Practice for Classification of Soils for Engineering Purposes (Unified Soil Classification System), ASTM International, West Conshohocken, PA, 2017.

[14] http://www.iricen.gov.in/LAB/res/pdf/test-12.pdf 